\title{
Morpho-tectonic evolution of the Çanakkale Basin (NW Anatolia): evidence for a recent tectonic inversion from transpression to transtension
}

\author{
Erkan Gökaşan • Tolga Görüm • Hüseyin Tur • \\ Fatmagül Batuk
}

Received: 22 May 2011 / Accepted: 29 September 2011 / Published online: 12 October 2011

(C) The Author(s) 2011. This article is published with open access at Springerlink.com

\begin{abstract}
Onshore and offshore seismic and geologicmorphologic evidence from the wider region of the Çanakkale Basin indicates that this area has been widely exposed to transpressional tectonism, which already commenced in the Pliocene. During this transpressional tectonism, the Gelibolu Fault and the Anafartalar Shear Zone on the Gelibolu Peninsula, as well as the Bozcaada-Biga Shear Zone on the Biga Peninsula were activated. As a consequence, the northern part of the Gelibolu Peninsula, and a broad zone between Bozcaada Island and the Karaburun Peninsula were uplifted to form the northern and southern boundaries of the Çanakkale Basin, respectively. This remained a low-elevation intermontane basin between these two highlands. The original morphol-
\end{abstract}

First author of the paper passed away in March 29, 2011.

E. Gökaşan · T. Görüm $(\bowtie)$

Natural Science Research Center, Y1ldı Technical University,

Esenler,

34220 İstanbul, Turkey

e-mail: tgorum@yildiz.edu.tr

H. Tur

Engineering Faculty, Department of Geophysics,

Istanbul University,

Avcilar,

34850 İstanbul, Turkey

F. Batuk

Civil Engineering Faculty, Department of Geomatic Engineering,

Yıldız Technical University,

Esenler,

34220 İstanbul, Turkey

Present Address:

T. Görüm

Faculty of Geo-Information Science and Earth Observation (ITC), University of Twente,

Hengelosestraat 99, P.O. Box 37, 7500AA Enschede, The

Netherlands ogy of the Çanakkale Basin may have developed as a coastal and shelf section of the large extensional Marmara Sea Basin at the end of the Late Miocene. This tectonic phase was followed in the Pliocene by the transpressional tectonism of the North Anatolian Fault Zone, which destroyed the initial morphology and formed the present V-shaped basin. The activity of the Gelibolu Fault and the Anafartalar Shear Zone along the northern boundary of the Çanakkale Basin ended in the late Pleistocene with the initiation of the northern segment of the North Anatolian Fault Zone. The tectonism along the northern boundary of the Çanakkale Basin thus shifted from a transpressional to a transtensional regime. Seismic data indicate that the Bozcaada-Biga Shear Zone continues to be active to the present day.

\section{Introduction}

The Çanakkale Basin is a NE-SW-oriented narrow depression lying between the Biga and Gelibolu peninsulas in NW Anatolia (Fig. 1). This elongated basin contains Late Miocene-Quaternary sediments, and is tectonically bounded by pre-Late Miocene volcanic-sedimentary rocks of the Biga and Gelibolu peninsulas (Erol 1968, 1992; Erol and Nuttal 1973; Saner 1985; Sümengen et al. 1987; Siyako et al. 1989; Okay et al. 1990; Elmas and Meriç 1998; Tüysüz et al. 1998; Yaltırak et al. 1998, 2000; Elmas 2003; Gökaşan et al. 2008, 2010; Ustaömer et al. 2008). The Çanakkale Strait (Dardanelles), which connects the Marmara and Aegean seas, passes longitudinally through the Çanakkale Basin (Fig. 1).

The Çanakkale Basin is located at the northeastern corner of the Aegean Sea between the Saros and Edremit gulfs on the west coast of Anatolia (Fig. 1). Several E-W-, NE-SW-, and NW-SE-oriented graben structures, which are filled by Miocene and younger 
Fig. 1 Location maps of the study area, showing the three segments of the North Anatolian Fault Zone in a digital elevation model of the Marmara region (modified after Barka and Kadinsky-Cade 1988; Șaroğlu et al. 1992; İmren et al. 2001; Gökașan et al. 2003; Ustaömer et al. 2008). The inset shows the North Anatolian and East Anatolian fault zones along the Anatolian Block. NS-, CS-, SS-NAFZ Northern, central, and southern segments of the North Anatolian Fault Zone, respectively, MS Marmara Sea, $C S$ Çanakkale Strait, IS Istanbul Strait, $I G$ İzmit Gulf, $G$ Gaziköy village, $K$ Kavakköy village, $G P$ Gelibolu Peninsula, $G G$ Gemlik Gulf

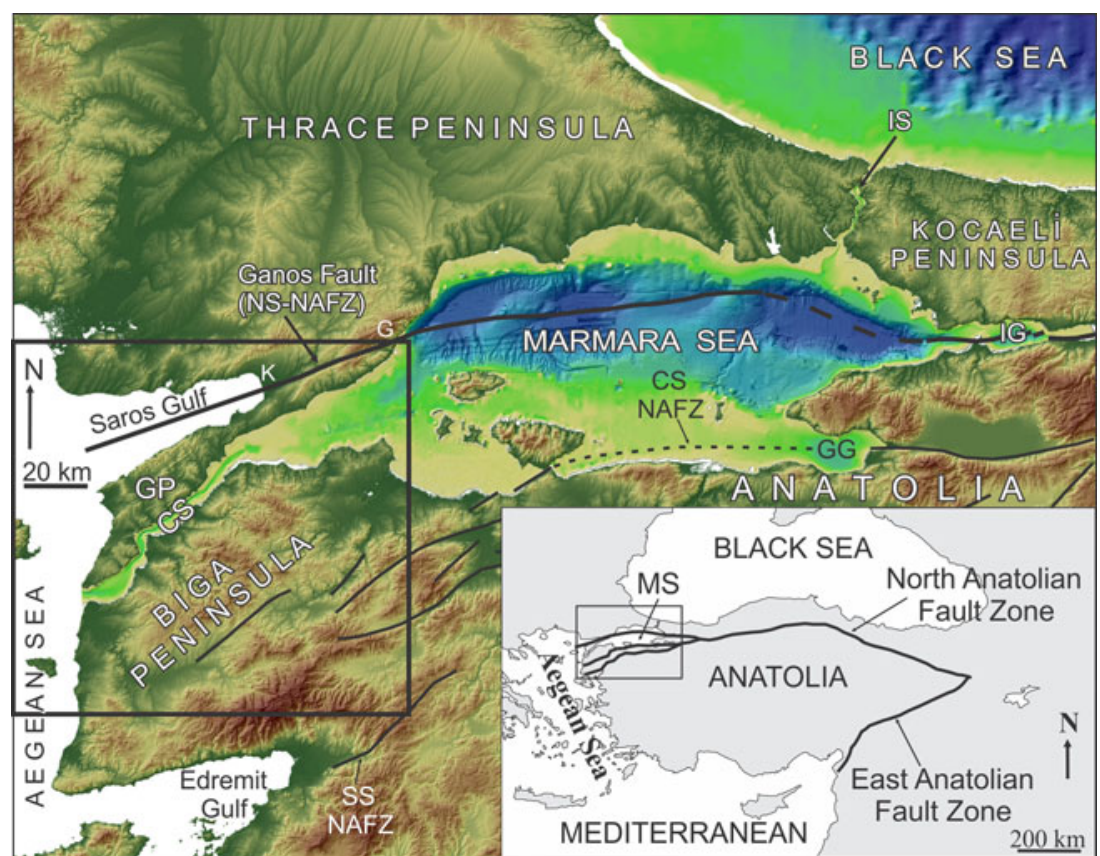

deposits, are located in western Anatolia where they are controlled by the N-S-oriented Aegean extensional regime (e.g., Şengör 1979, 1980; Seyitoğlu and Scott 1994; Yllmaz et al. 2000). These graben structures find their morphological expression in a number of gulfs located along the shoreline-for example, the Saros and Edremit gulfs, and their landward extensions in wide river valleys. Although the Çanakkale Basin has some similarities with the graben structures in terms of its location, orientation, and sedimentary fill, the northern boundary is not extensional in origin but was formed by a northwestfacing thrust fault, the Anafartalar Fault (Saner 1985; Elmas and Meriç 1998; Yaltırak et al. 1998, 2000). Therefore, unlike the graben system in western Anatolia, the evolution of the Çanakkale Basin has partly or completely been controlled by compressional tectonics.

Previous studies in the northeastern corner of the Aegean Sea primarily focused on the evolution of the Saros Gulf (Saner 1985; Tüysüz et al. 1998; Yaltırak et al. 1998; Saatçlar et al. 1999; Kurt et al. 2000; Ustaömer et al. 2008), the Çanakkale Strait (Yalçınlar 1949; Erol 1968, 1992; Elmas and Meriç 1998; Yaltırak et al. 2000; Gökaşan et al. 2008, 2010) and the Ganos Fault, the latter being the western continuation of the northern segment of the North Anatolian Fault Zone (NS-NAFZ; Saner 1985; Elmas and Meriç 1998; Tüysüz et al. 1998; Yaltırak et al. 1998, 2002; Okay et al. 1999, 2004; Ustaömer et al. 2008). The Çanakkale Basin has therefore been considered to have formed during the evolution of the Saros Gulf. Yet, only very few studies have focused on the basin itself (Elmas and Meric 1998; Yaltırak et al. 2000). In addition, the present tectonic activity of the Çanakkale Basin has in the past not been clearly linked to the NS-NAFZ, which has been interpreted as a transtensional fault in the Saros Gulf (Taymaz et al. 1991; Yaltırak and Alpar 2002; Karabulut et al. 2006; Ustaömer et al. 2008).

In this study, we focus on the morpho-tectonic development of the Çanakkale Basin, which is represented by Late Miocene and younger units exposed along the coast of the Çanakkale Strait (Fig. 2a). We used high-resolution seismic and bathymetric/topographic data as well as field investigations to (1) evaluate the basin architecture and its relation to the tectonic elements; (2) identify the characteristics of the late Pleistocene-Holocene tectonism; and (3) address the role of these tectonic structures in the evolution of the Çanakkale Basin.

\section{Materials and methods}

High-resolution single-channel seismic and multi-beam bathymetric data were collected between 1979 and 2005 in the course of numerous cruises onboard the TCG Çubuklu operated by the Turkish Navy, Department of Navigation, Hydrography and Oceanography (TN-DNHO; Fig. 2a). Multi-channel seismic data were collected in 1995 on board the R/V MTA Seismic 1 operated by the General Directorate of Mineral Research and Exploration.

The seismic data were previously evaluated by Çağatay et al. (1998), Demirbağ et al. (1998), Yaltırak et al. (1998, 2000), Gökașan et al. (2003, 2008, 2010) and Ustaömer et al. (2008), and the bathymetric data partly or completely by Gökaşan et al. $(2008,2010)$ and Ustaömer et al. (2008). All the seismic and bathymetric profiles considered in the present study are shown on Fig. 2. 
Fig. 2 a Simplified geological map of the Çanakkale Basin and surrounding area (compiled from Erol and Nuttal 1973; Sümengen et al. 1987; Siyako et al. 1989; Okay et al. 1990; Yaltırak et al. 2000). ASZ Anafartalar Shear Zone, $A G$ Araplar Gorge, $B$ Bozcaada Island, $G$ Gökçeada Island, bold lines locations of seismic profiles. b Geological section A-B along the line crossing the Gelibolu Peninsula (not to scale; see a for location)

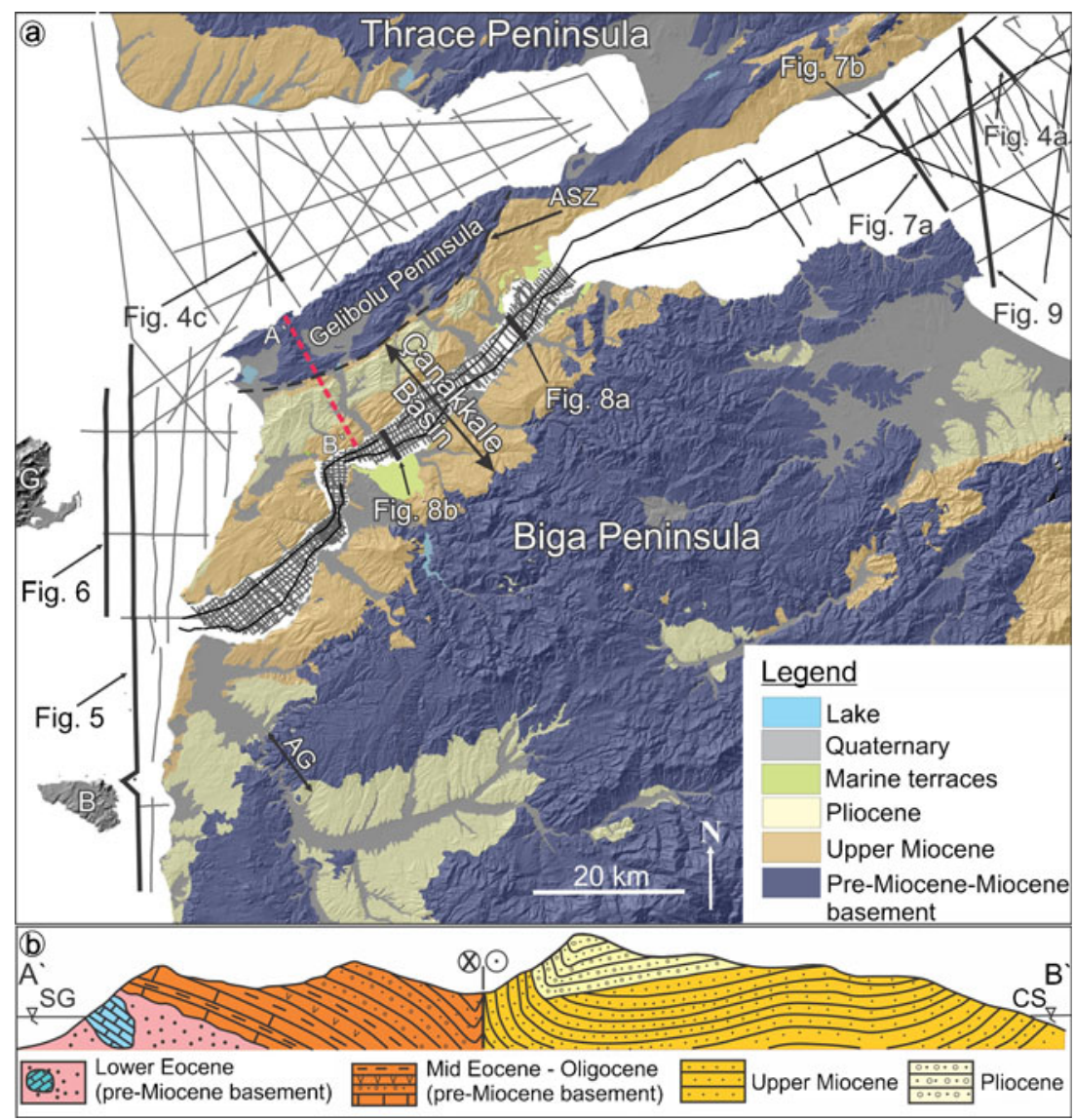

\section{Results}

Morpho-tectonic situation in the Marmara region

The modern morphology of the Marmara region, which consists of the Marmara Sea and its surroundings, including the Biga and Gelibolu peninsulas, mostly reflects remnants of a mature horizontal erosion surface termed the ThraceKocaeli peneplain (Cvijic 1908; Pamir 1938; Emre et al. 1998; Erinç 2000; Elmas 2003; Gökaşan et al. 2005, 2008; Yilmaz et al. 2010). According to Yilmaz et al. (2010), the erosion of this peneplain took place from the Late Oligocene to the end of the Late Miocene. Since the end of the Miocene, the Thrace-Kocaeli peneplain has been rejuvenated by neotectonic activity controlled by the Aegean extensional regime and the North Anatolian Fault Zone (Y1lmaz et al. 2010). During the initial phase of neotectonic activity, the Marmara Sea Basin developed under $\mathrm{N}-\mathrm{S}$ extensional tectonism, in the course of which some fragments of the peneplain were lowered by normal faulting, thereby creating new base levels for deposition. Both the Saros Gulf and the Canakkale Basin are thus lowered parts of this surface, whereas the Thrace and Biga peninsulas constitute the elevated ridges separating the basins. The transtensional phase was followed by dextral shear tectonics of the North Anatolian Fault Zone (Le Pichon et al. 2001; Gökaşan et al. 2003; Şengör et al. 2005; Y1lmaz et al. 2010).

The North Anatolian Fault Zone (NAFZ) is the main tectonic element controlling the present-day tectonic regime in the Marmara region. It is a 1,500-km-long dextral strike-slip fault extending across northern Anatolia from the Karlova region in the east to the northern Aegean Sea in the west (Ketin 1948; Șengör 1979; Şengör et al. 1985, 2005; Barka and Kadinsky-Cade 1988; Şaroğlu et al. 1992; Reilinger et al. 1997; see inset of Fig. 1). To the east of the Marmara Sea, the NAFZ bifurcates into three segments. The NSNAFZ, which is the most active of these, extends into the Marmara Sea via the İzmit Gulf, thereby dissecting the approximately ENE-WSW-oriented deep Marmara Basin, whereas the central segment (CS-NAFZ) passes through the Gemlik Gulf and then follows the southern coastline of the Marmara Sea (Barka and Kadinsky-Cade 1988; Wong et al. 1995; İmren et al. 2001; Le Pichon et al. 2001; Armijo et al. 2002; Gazioğlu et al. 2002; Gökaşan et al. 2003; Gürer et al. 2003, 2006). The southern segment (SS-NAFZ), in turn, passes through the terrestrial area south of the Marmara Sea (Barka and Kadinsky-Cade 1988; Gürer et al. 2003, 2006; Fig. 1). Considering the geodetic velocities and the offset in the western submarine ridge in the Marmara Sea (Fig. 3a), 
Le Pichon et al. (2001) suggested that the NS-NAFZ has developed in the Marmara Sea since 200 ka B.P.

Just before the NS-NAFZ reaches the northwest coast of the Marmara Sea, it changes its direction by $17^{\circ}$ toward the south, being also known as the Ganos Fault (Fig. 1) from there onward (Okay et al. 2004). This change in orientation forms a restraining bend in the fault zone, which adds a compressional component to the NS-NAFZ (Okay et al. 1999, 2004; Yaltırak and Alpar 2002; Gökaşan et al. 2003). The compressional nature of this fault can be clearly seen in a seismic section located south of Gazikoy village where the fault enters Thrace (Fig. 4a). Onland, the compressional component of the NS-NAFZ is revealed by sharply increased inclinations of the Upper Miocene units toward the fault, and by the
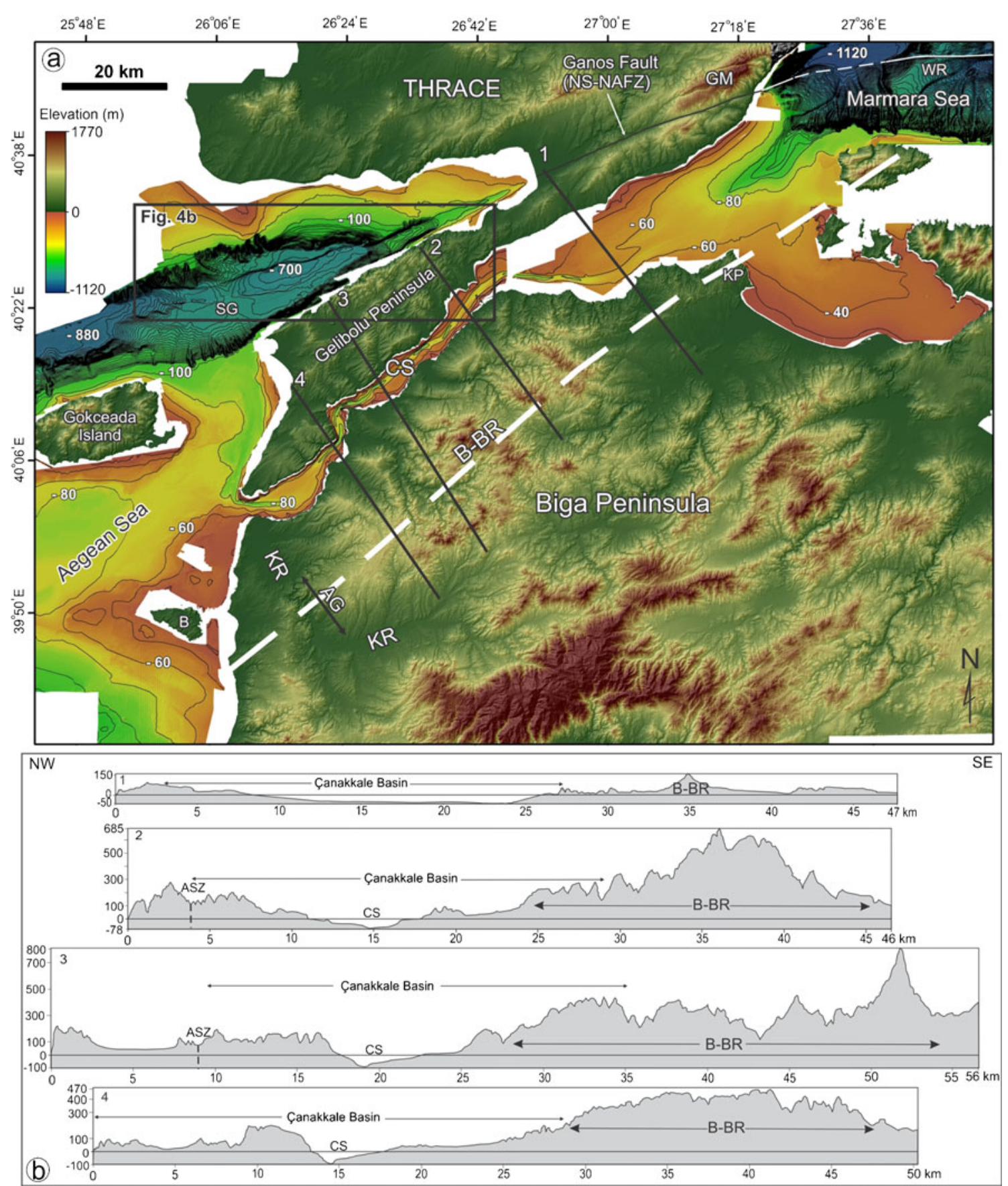

Fig. 3 a Digital elevation model of the Çanakkale Basin and surrounding areas (modified after Gökaşan et al. 2010). B-BR Bozcaada-Biga Ridge, $A G$ Araplar Gorge, $G M$ Ganos Mountains, $K R$ Karamenderes River, $K P$ Karaburun Peninsula, $W R$ western ridge,
$S G$ Saros Gulf, $B$ Bozcaada Island, lines 1-4 locations of topographic profiles. b Topographic profiles across the onland part of the Canakkale Basin (see a for locations). ASZ Anafartalar Shear Zone, $C S$ Çanakkale Strait, $B-B R$ Bozcaada-Biga Ridge 
Fig. 4 a High-resolution seismic profile cross-cutting the offshore extension of the Ganos Fault (NS-NAFZ) along the western margin of the Marmara Sea (see Fig. 2a for profile location). $M$ Multiple. b Multi-beam bathymetric map showing surface ruptures of the Ganos Fault and the inner depression (ID) along the Saros Gulf (modified after Ustaömer et al. 2008). The inset shows the detailed morphology of back-tilted blocks, indicating the transtensional character of the Ganos Fault (thick white thick arrow view direction $(v d)$ of inset; see Fig. 3a for location). Focal mechanism solutions were compiled from Taymaz et al. (1991) and Karabulut et al. (2006). c High-resolution seismic profile from the Saros Gulf, showing the Ganos Fault and the inner basin (modified after Ustaömer et al. 2008; see Fig. 2a for profile location)
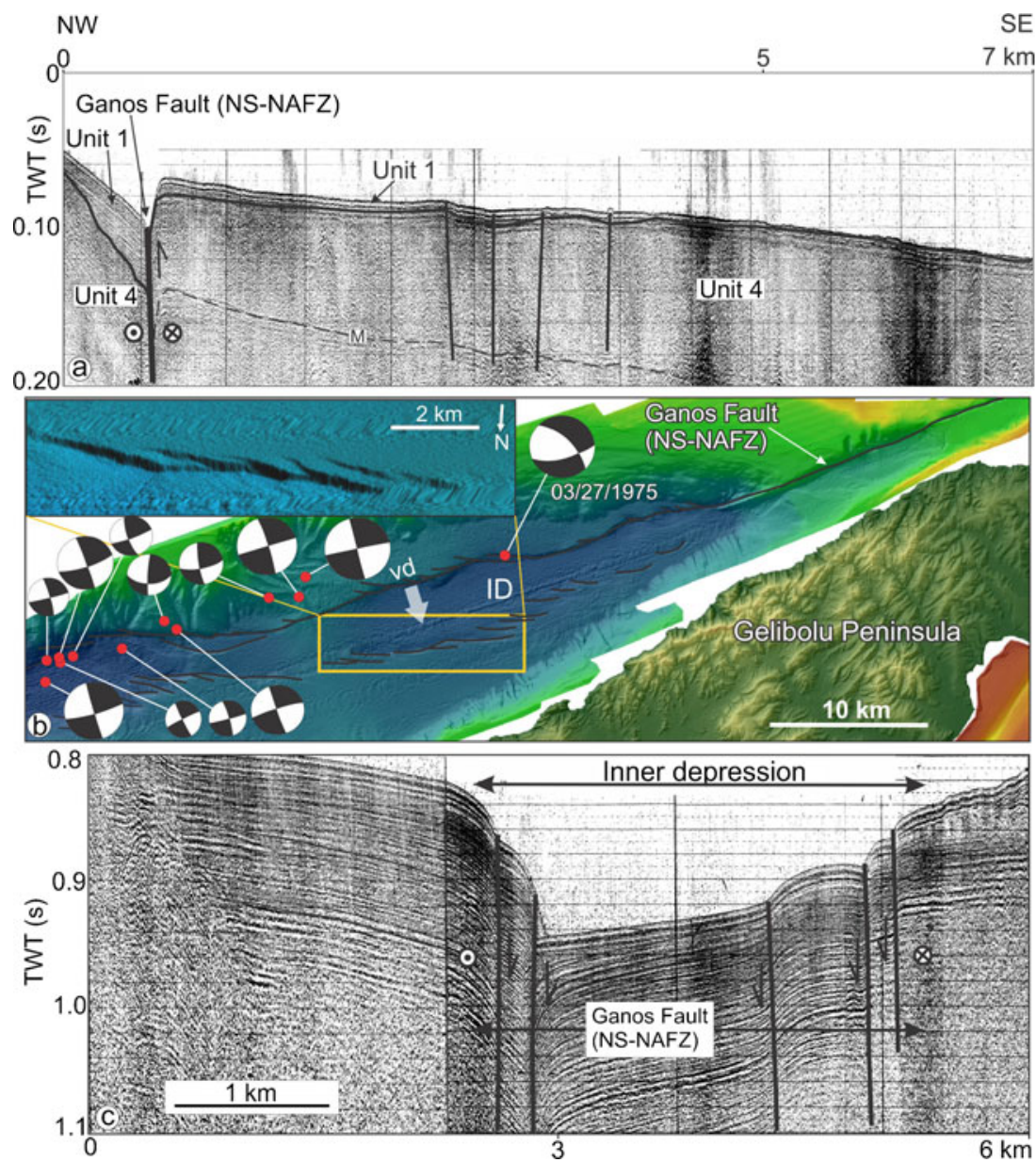

uplifted Ganos Mountains as a restraining ridge (e.g., Tüysüz et al. 1998; Yaltırak and Alpar 2002; Okay et al. 2004).

In the Saros Gulf and the NE Aegean Sea, the character and geometry of the Ganos Fault (NS-NAFZ) were investigated in detail by Ustaömer et al. (2008) on the basis of highresolution swath bathymetric and seismic data. They showed that the western extension of the Ganos Fault longitudinally dissects the Saros Gulf into a narrow deformation zone along the eastern shelf margin of the gulf, and two NE-SWoriented fault zones along the adjacent basin floor (Ustaömer et al. 2008; Fig. 4b). These latter two fault zones, which cut the basin floor along its central axis, have generated a new Riedel-type pull-apart basin (inner depression), which gives the Ganos Fault in the Saros Gulf a transtensional character (Ustaömer et al. 2008; Fig. 4b, c). The transtensional nature of the fault was also highlighted by the analyses of the 1975 earthquake (Taymaz et al. 1991), and the earthquake sequence of 2003 (Karabulut et al. 2006; Fig. 4b). These observations indicate that the transpressional character of the Ganos Fault (NS-NAFZ) along the Ganos Mountains is replaced by a transtensional one in the Saros Gulf.

Under these morpho-tectonic circumstances, the present morphology of the Çanakkale Basin is represented by a
NE-SW-oriented lowland located between the Biga and Gelibolu peninsulas (Fig. 2a, b). The southern boundary of the basin is morphologically clearly visible along the Biga Peninsula as a NE-SW-trending highland stretching from Bozcaada Island in the south to the Karaburun Peninsula in the north (Figs. 2, 3). This highland is called the BozcaadaBiga Ridge (B-BR; Fig. 3a, b, profiles 1-4). The northern boundary of the basin, on the other hand, is morphologically less clear. In the eastern and central parts of the Gelibolu Peninsula, the northern boundary forms the most elevated area of the peninsula (Figs. 2, 3a, b, profiles 1 and 2). In the western parts of the peninsula, by contrast, the morphologically highest zone is formed by Pliocene clastics, and the northern boundary of the basin lies under an alluvial plain. This means that the northern boundary of the basin is not well pronounced in the morphology along this part of the peninsula (Figs. 1, 3a, b, profiles 3 and 4).

Depositional sequences of the Çanakkale Basin

The sediments of the Canakkale Basin, which consist of Late Miocene and younger (Pliocene, Quaternary) deposits, unconformably overlie the pre-Miocene to Miocene base- 
ment cropping out on the Gelibolu and Biga peninsulas (Fig. 2). On the Gelibolu Peninsula, the basin deposits are delimited by a northwest-facing thrust fault (the Anafartalar Thrust Fault) that runs parallel to the axis of the peninsula (Saner 1985; Yaltırak et al. 1998, 2000; Yaltırak and Alpar 2002; Fig. 2). The basin deposits are also delimited by a tectonic unconformity on the Biga Peninsula where the preMiocene to Miocene basement crops out in the hinterland (Elmas and Meriç 1998).

Upper Miocene sediments consist of siliciclastic and limestone particles deposited in fluvio-lacustrine, beach, and shallow marine environments, in addition to some volcanic rocks that crop out on both sides of the Çanakkale Strait (Erol 1968; Erol and Nuttal 1973; Sümengen et al. 1987; Elmas and Meriç 1998; Tüysüz et al. 1998; Yaltırak et al. 1998, 2000; Sakınç and Yaltırak 2005; Fig. 2b). The Upper Miocene sediments are overlain by Pliocene clastics (the Conkbayırı Formation; Sümengen et al. 1987; Yaltırak et al. 1998) and Quaternary marine terraces (Erol and Nuttal 1973; Yaltırak et al. 2002; Fig. 2). U/Th dates indicate that the onland marine terraces were emplaced between 200 and 50 ka B.P. (Yaltirak et al. 2002). Alluvial sediments along the Çanakkale Strait and the coasts of the SW Marmara Sea and the NE Aegean Sea constitute the most recent deposits of the Çanakkale Basin.

The same stratigraphic sequence is observed on seismic records from the Çanakkale Strait and its exits to the Marmara and Aegean shelves. Thus, four seismic units (units 1, 2, 3, and 4) have been distinguished in the Çanakkale Basin on top of a basement reflector representing the upper surface of the Early-Middle Miocene and pre-Miocene rocks identified in previous studies (Smith et al. 1995; Çağatay et al. 1998; Yaltırak et al. 2000; Ergin et al. 2007; Gökaşan et al. 2008, 2010; Figs. 4a, 5, 6, 7, 8, 9).

Unit 4 is the lowermost unit observed on the highresolution seismic profiles (Figs. 4a, 5, 6, 7, 8). It has been interpreted as the submarine extension of the Upper
Miocene deposits of the Çanakkale Basin (Yaltırak et al. 2000; Gökaşan et al. 2008; Fig. 2). High-amplitude, continuous parallel reflectors of unit 3 terminate with onlaps and downlaps onto the erosional upper surface of unit 4 (Figs. 5, 6, 7). Unit 3 was observed mainly on the Aegean and Marmara shelves (Smith et al. 1995; Çağatay et al. 1998; Ergin et al. 2007; Gökaşan et al. 2010). In the Çanakkale Strait, this unit has been interpreted as the submarine extensions of the onland marine terraces lining the coastline (Gökaşan et al. 2008, 2010; Fig. 2). The boundary between units 2 and 3 is formed by a regional erosion surface that developed on the shelf of the Marmara Sea during the last glacial period at the late PleistoceneHolocene transition (Smith et al. 1995; Ergin et al. 1997; Aksu et al. 1999; Gökaşan et al. 2010). This unconformity was dated as having been formed between $\sim 23$ and $12 \mathrm{ka}$ B.P. (Hiscott and Aksu 2002). Unit 2 represents a deltaic deposit, as revealed by its oblique-sigmoidal reflectors developed on the erosional unconformity during the deglaciation period of the last glacial stage along the Aegean and Marmara sea exits of the Çanakkale Strait (Smith et al. 1995; Gökaşan et al. 2010). Along the Çanakkale Strait, this unit occurs only off the modern river mouths, indicating that it forms the offshore extensions of modern alluvial deposits (Gökaşan et al. 2008, 2010). Unit 1 represents the uppermost deposits in the study area (Figs. 4a, 5, 6, 7, 8). It comprises flat-lying parallel reflectors terminating with onlaps and downlaps onto the older units. The uppermost layer of unit 1 forms the modern seafloor, and thus probably constitutes the most recent offshore deposits of the Çanakkale Basin (Gökașan et al. 2008, 2010).

\section{Structural features along the Çanakkale Basin}

Structural features along the Çanakkale Basin are observed both onland and offshore. Onland, the transpressional

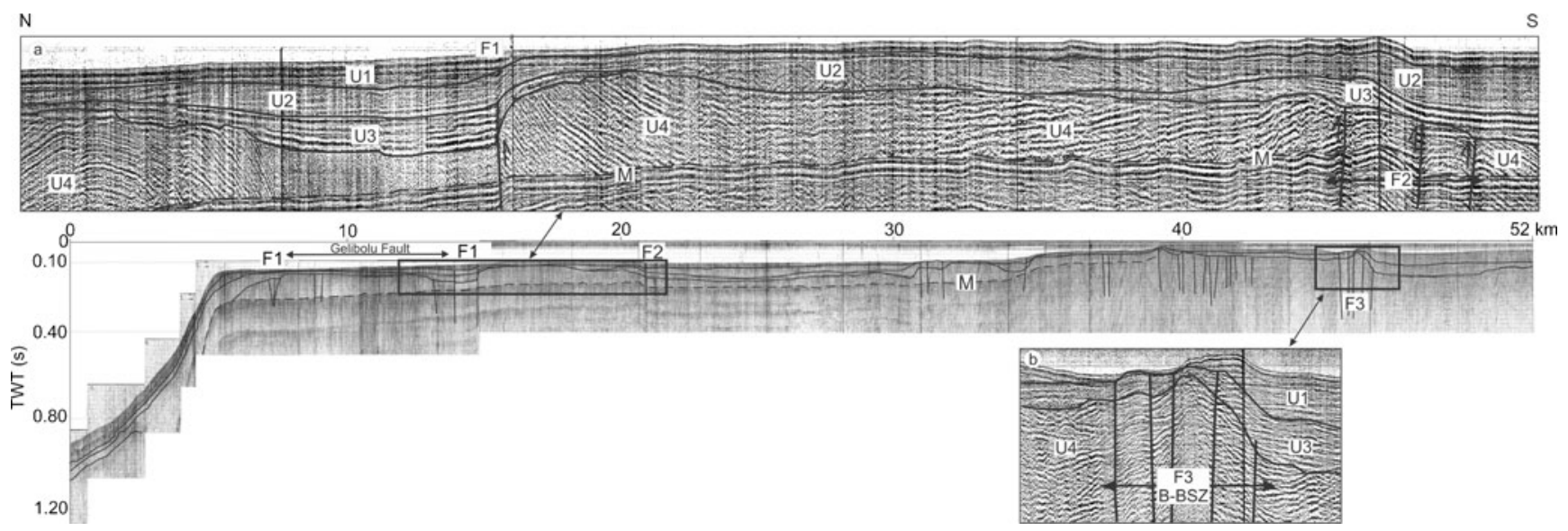

Fig. 5 N-S-oriented seismic profile from the NE Aegean Sea shelf (modified after Çağatay et al. 1998). The insets show detailed interpretations (see Fig. 2a for location). U1-4 Depositional units, F1-3 faults, B-BSZ Bozcaada-Biga Shear Zone, $M$ multiple 


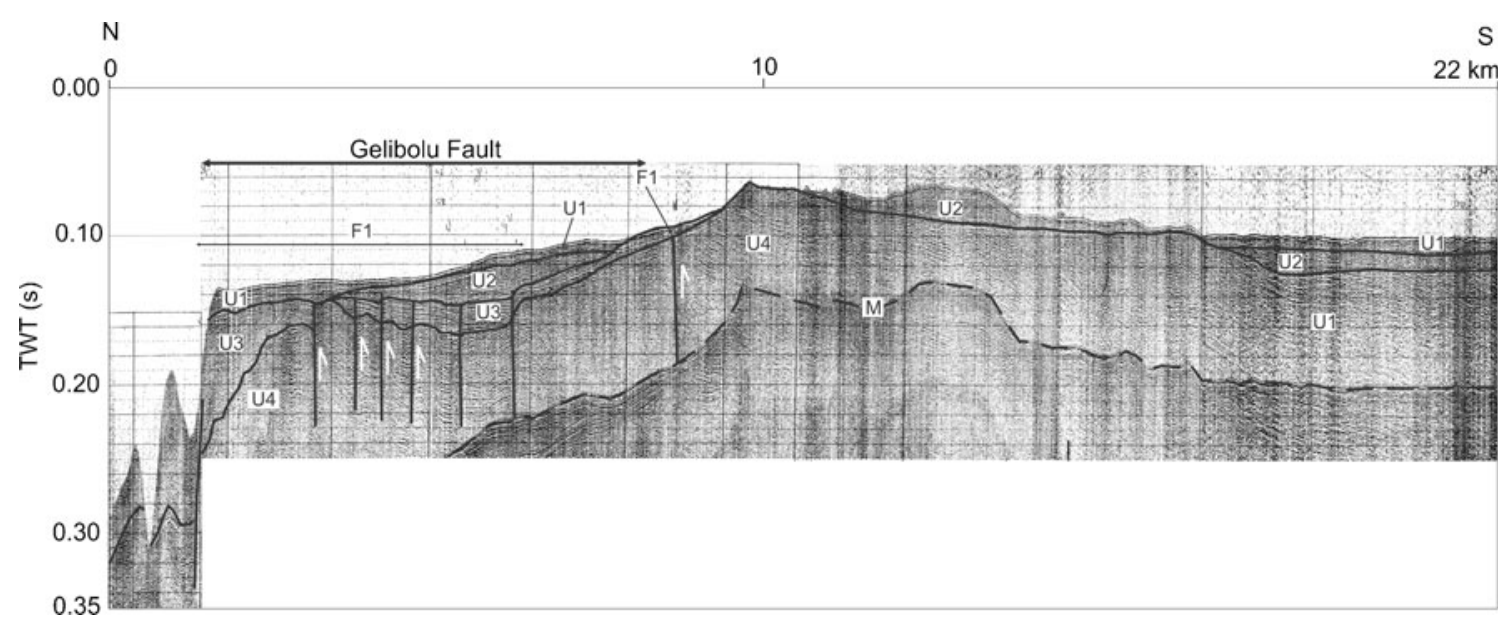

Fig. 6 N-S-oriented seismic profile from the NE Aegean Sea shelf, offshore Gökçeada Island (see Fig. 2a for location). U1-4 Depositional units, $F 1$ fault, $M$ multiple

structures on the Gelibolu Peninsula are widely developed in the Late Miocene and Pliocene deposits. The structures are represented by NE-SW- and ENE-WSW-trending folds, recumbent beds, small-scale thrust faults, and high-angle strike-slip faults. The Anafartalar Shear Zone (ASZ; called the Anafartalar Thrust Fault in Yaltırak et al. 1998, 2000, and Yaltırak and Alpar 2002) is the most dominant structure on the Gelibolu Peninsula. It is a convex shear zone that is clearly visible in the NE part of Gelibolu (Fig. 2a). The shear zone is a vertical to subvertical, narrow $(50-100 \mathrm{~m})$ deformation zone marked by highly altered red-green rocks comprising clay, silt, and sand with interspersed fault breccia. The units both to the $\mathrm{N}$ and $\mathrm{S}$ have steeper angles toward the shear zone, and in some places even overturn (Fig. 2b). The recumbent beds are developed toward the eastern limb of the convex shear zone. Here, both the Miocene and the unconformably overlying Pliocene sediments overturn toward the south with steep angles. Small-scale thrust faults are observed in the Late Miocene units, and small-scale strike-slip faults occur in both the Late Miocene and Pliocene deposits. The strike-slip faults have a dominant NE-SW trend with a dextral sense of shear.

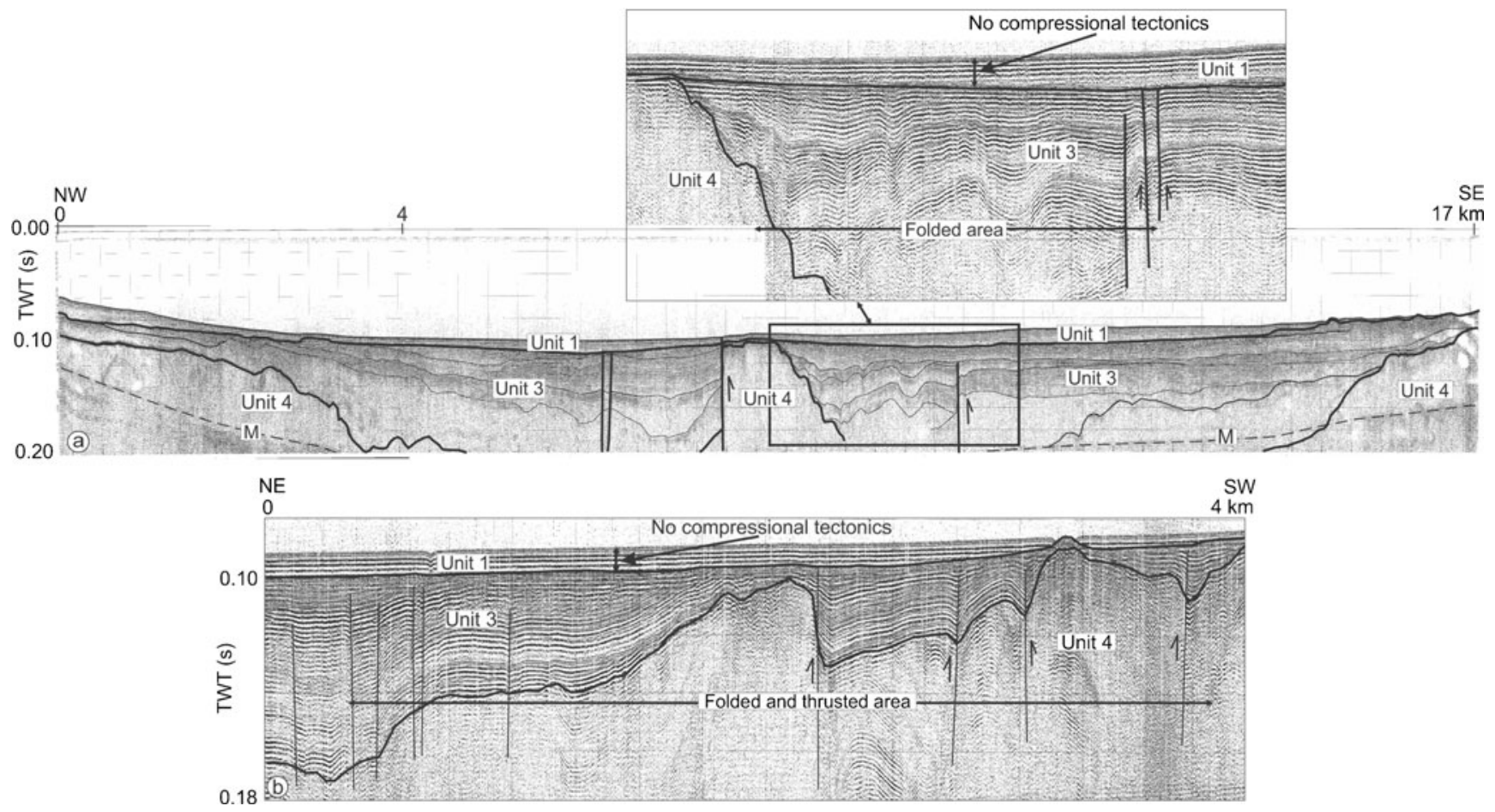

Fig. 7 a NW-SE- and b NE-SW-oriented seismic profiles from the Marmara Sea exit of the Çanakkale Strait (modified after Ergin et al. 2007; see Fig. 2a for locations). $M$ Multiple 
Fig. 8 a NW-SE-oriented highresolution seismic profile from the Çanakkale Strait. b NWSE-oriented high-resolution seismic profile from off the Nara Cape in the Çanakkale Strait, showing the active transtensional Nara Fault (both profiles after Gökaşan et al. 2008; see Fig. 2a for locations). $M$ Multiple

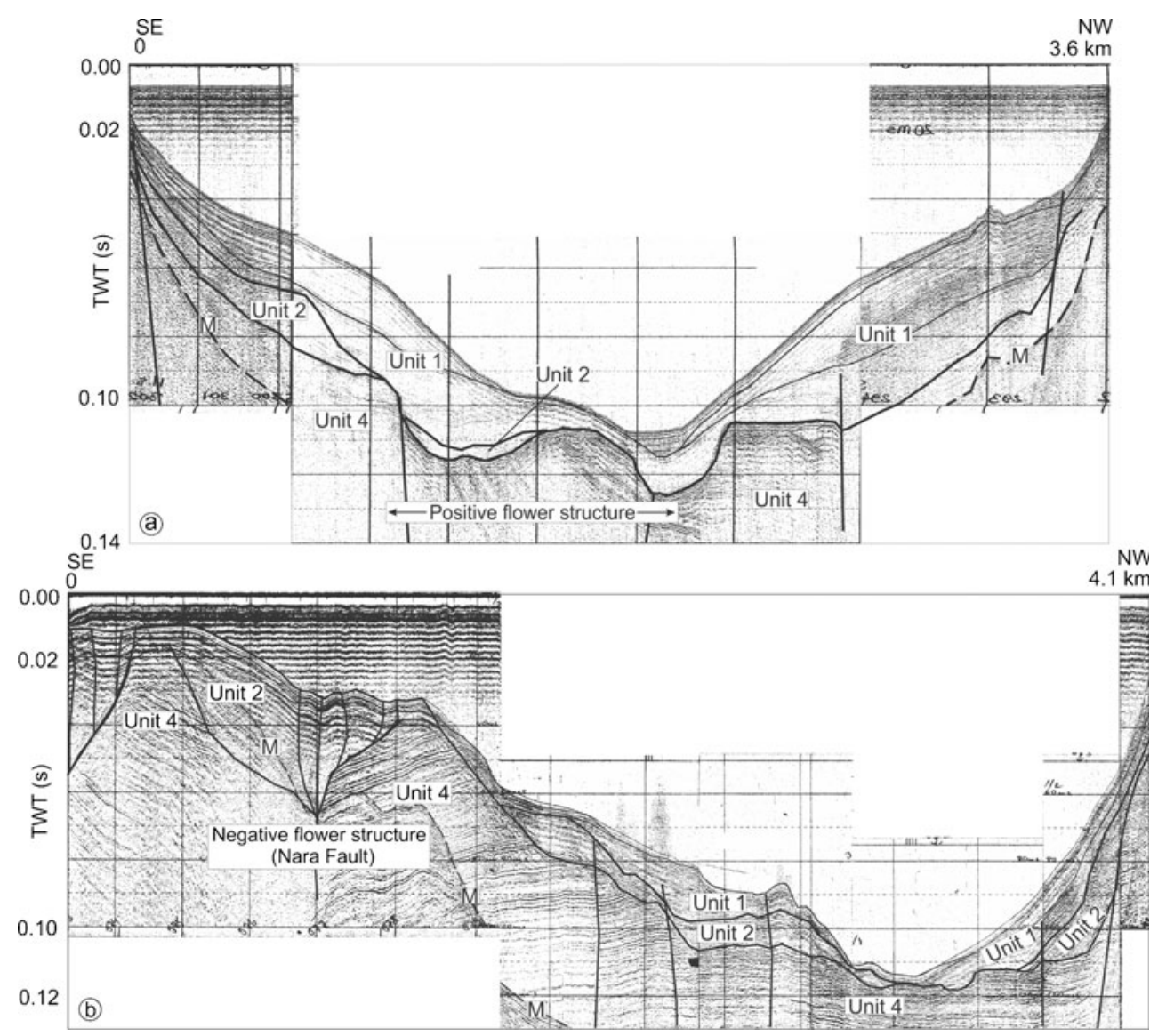

In the offshore, the initially parallel reflections of units 1 to 4 are deformed along some sections (Figs. 4a, 5, 6, 7, $8,9)$ where the originally horizontal or very slightly inclined reflectors dip at high angles. These irregular zones are interpreted as faults (Fig. 10), the most important one being the Ganos Fault (Figs. 4a-c, 10). As mentioned above, the transtensional character of the Ganos Fault is clearly seen on both seismic and bathymetric data along the Saros Gulf (Ustaömer et al. 2008; Fig. 4b, c), whereas field observations and seismic records from the western margin of the Marmara Sea show it to have a transpressional character in this region (e.g., Okay et al. 1999; Fig. 4a).

Structural features are also seen in the Çanakkale Strait and its Aegean and Marmara sea exits. Three of these (faults F1, F2, F3) can be seen at the Aegean Sea exit (Figs. 5, 6, 10). Vertical displacements and accompanying folds in the reflectors of units 3 and 4 along the fault zones are clearly evident on the seismic records, indicating that these faults are products of compressional tectonics (Figs. 5, 6). The northernmost member of these faults (fault zone F1)

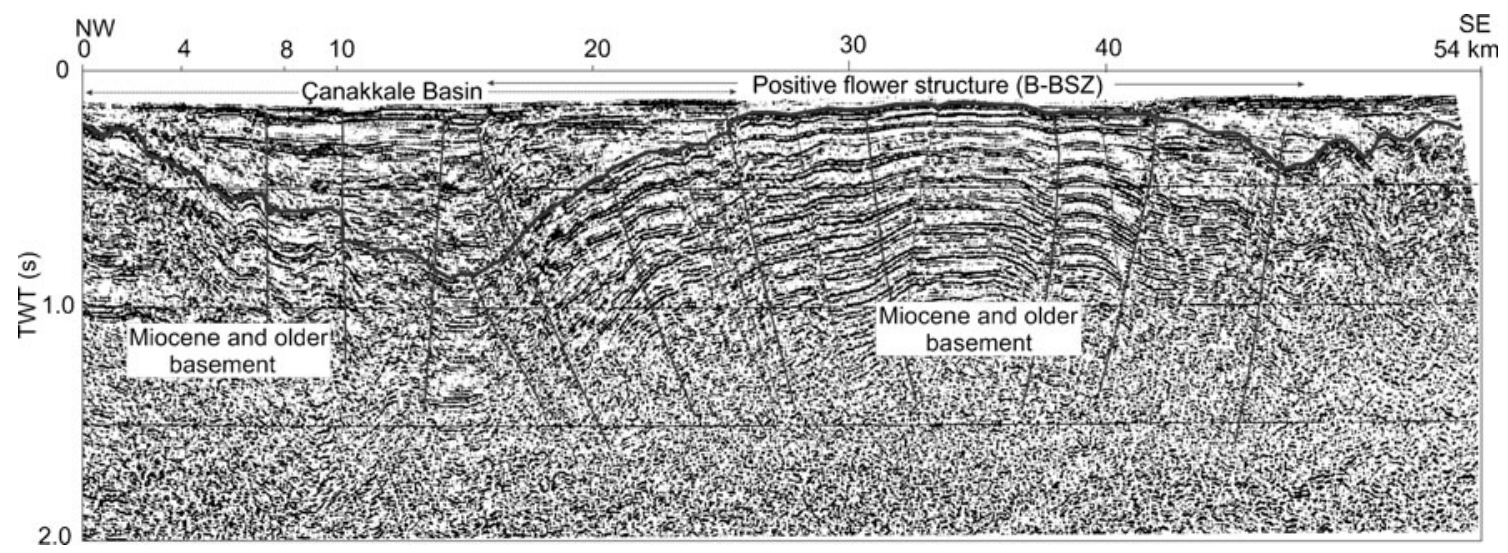

Fig. 9 NW-SE multi-channel seismic profile from the SW Marmara Sea shelf (modified after Ergin et al. 2007; see Fig. 2a for location). B-BSZ Bozcaada-Biga Shear Zone 


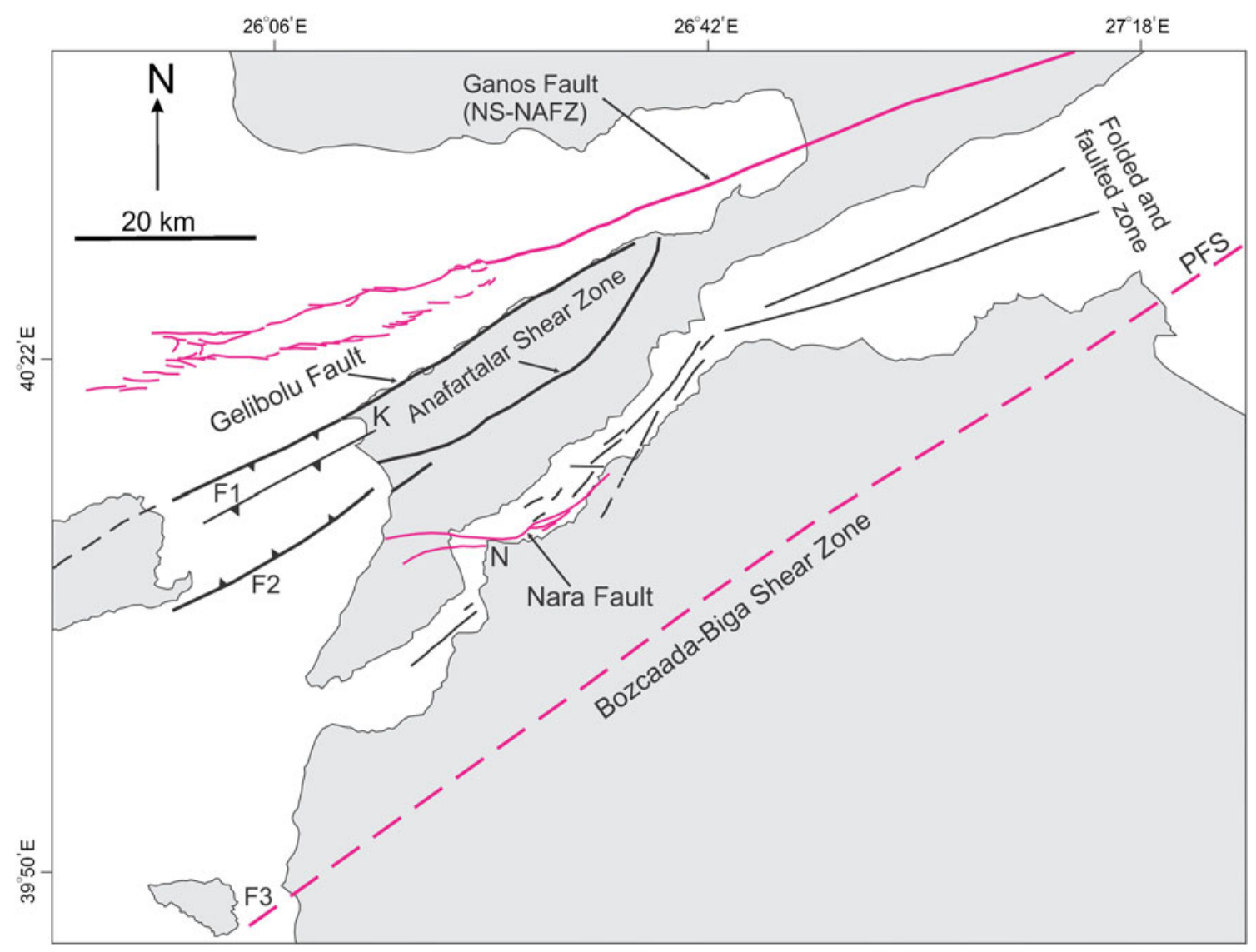

Fig. 10 Locations of major faults in the study area. Red lines Active transtensional faults, black lines inactive transpressional faults, F1-3 faults, $K$ Kemikli Cape, $N$ Nara Cape, PFS positive flower structure (compiled from Gökaşan et al. 2008, Ustaömer et al. 2008, and this study)

consists of two segments, one located along the shelf edge between Gökçada Island and Cape Kemikli on the Gelibolu Peninsula, the other one just south of the shelf edge, running parallel to the shelf-slope transition (inset a of Figs. 5, 6, 10). The dramatically inclined and folded reflectors of units 3 and 4 in the foot wall, and the increasing inclinations of the reflectors toward the fault zone in the hanging wall of the southerly dipping faults of fault zone F1 indicate a north-verged reverse fault system (inset a of Figs. 5, 6). Another reverse fault (fault F2) runs from the southeastern tip of Gökçeada Island toward the western shore of the Gelibolu Peninsula (inset a of Figs. 5, 10). Contrary to fault F1, this fault seems to be a southverged reverse fault (inset a of Fig. 5). South of the Çanakkale Strait exit, between Bozcaada Island and the Biga Peninsula, a NE-SW-oriented fault (fault F3) is observed on the seismic profiles (inset b of Fig. 5). This fault is characterized by up-thrown internal reflectors of units 3 and 4, indicating that fault F3 represents a positive flower structure of a strike-slip fault (inset b of Fig. 5).

Gökașan et al. $(2008,2010)$ showed that some of the faults along the central axis of the Canakkale Strait evidently controlled the erosion that formed the strait itself. On a seismic profile from the northern part of the Çanakkale Strait, the horizontal to low-angle inclinations of unit 4 reflectors dramatically increase along part of the central axis of the strait (Fig. 8a). In this section, unit 4 is seen to be uplifted by approximately $20 \mathrm{~ms}$, the sediments of unit 2 having been deposited in the trough formed at the eastern limb of the uplift. This suggests the existence of a positive flower structure associated with a strike-slip fault along the northern part of the Çanakkale Strait (Figs. 8a, 10). Gökaşan et al. $(2008,2010)$ also identified a strike-slip fault that follows the northern coastline of the Nara Cape, cross-cuts the N-Soriented part of the strait, and then enters the Gelibolu Peninsula (Figs. 8b, 10). This fault has been named the Nara Fault (Gökaşan et al. 2008, 2010). Because the reflectors of units 2 and 4 located within the Nara Fault have been lowered together with the seafloor, this fault is interpreted to represent a negative flower structure (Fig. 8b).

At the Marmara Sea entrance of the Çanakkale Strait, compressional features such as folding and reverse faulting are also seen as major structures on the seismic profiles (Fig. 7a, b). Here, units 3 and 4 have been folded and uplifted by reverse faults and folds. The most significant structure in the Marmara Sea entrance of the Çanakkale 
Strait occurs off the Karaburun Peninsula. It has been recorded on a NNW-SSE-oriented multi-channel seismic profile (Fig. 9). On the eastern side of the profile, from $\mathrm{km}$ 15 to 47, the seismic reflectors of the Lower-Middle Miocene and older rocks are uplifted to form a broad ridge. Since uplifted parallel reflectors of the basement are discontinued and vertically displaced along ruptures, the uplifting process is evidently controlled by the broad shear zone of a fault forming a positive flower structure, rather than an anticline. This suggests the existence of a wide transpressional fault zone located off the Karaburun Peninsula (Figs. 9, 10).

\section{Discussion and conclusions}

Modes and timing of transpressional tectonics

Seismic interpretations as well as field studies indicate that the Çanakkale Basin and its vicinity have been affected by a number of faults (Fig. 10). Most of these faults have compressional character such as reverse or transpressional faulting, which indicates that the Çanakkale Basin has experienced compressional tectonism in its history. Of these, faults F1, F2, and F3, as well as the fault off the Karaburun Peninsula, are interpreted as major compressional faults.

Two of the faults (faults F1 and F2) located on the NW Aegean Sea shelf between the Gelibolu Peninsula and Gökçeada Island are interpreted to represent reverse faults verging toward the north and south, respectively (Figs. 5, 6). The northern member, the Gelibolu Fault (fault F1), overlies the southern slope of the Saros Gulf, while lining up farther east with the northern linear coastline of the Gelibolu Peninsula (Fig. 10). This fault coincides with the northern boundary fault of the Gelibolu Peninsula, which was named the Gelibolu Fault (fault F1) by Yaltırak and Alpar (2002). Fault F2, on the other hand, is well correlated with the ASZ on the Gelibolu Peninsula (Fig. 10). Seismic data show that the area between faults F1 and F2 has been uplifted to form the northern boundary of the Çanakkale Basin, as previously suggested by Yaltirak (1995). The Pliocene-aged Conkbayırı Formation (Okay et al. 1990), which was deposited when the northern boundary of the Çanakkale Basin was uplifted by the Gelibolu Fault and the ASZ (Yaltırak 1995), indicates that both the Gelibolu Fault and the ASZ have been activated in the Pliocene. On seismic profiles from the Aegean shelf, faults F1 and F2 are observed to affect only seismic units 3 and 4 ; hence, units 1 and 2 are not cut by these faults. This observation is confirmed by the presence of the compressional structures on the western shelf of the Marmara Sea at the Çanakkale Strait exit where no compressional effects are observed in the sediments of unit 1 and the erosional surface at the top of unit 3, indicating that compressional tectonics ended prior to the formation of units 1 and 2. These, in turn, indicate that the activity of faults $F 1$ and F2, i.e., the Gelibolu Fault and the ASZ, ended in the late Pleistocene.

The present-day tectonic activity along the Saros Gulf and the Çanakkale Strait, and hence the northern boundary of the Çanakkale Basin, is controlled by the transtensional Ganos and Nara faults, and not by the Gelibolu Fault and the ASZ (Fig. 10). Ustaömer et al. (2008) suggested that the Ganos Fault (NS-NAFZ) was a very recent feature in the Saros Gulf. The eastern extension of this fault in the Marmara Sea was interpreted to have been activated some 200 ka B.P. (Le Pichon et al. 2001). The NS-NAFZ (Ganos Fault) along the Marmara Sea and the Saros Gulf was thus initiated in the late Pleistocene, at the time when the Gelibolu Fault and the ASZ became inactive.

Fault F3 is a transpressional fault located on the Aegean shelf between Bozcaada Island and the Biga Peninsula. The positive flower structure of this fault correlates with the B-BR on the Biga Peninsula where it forms the SW boundary of the Çanakkale Basin (Fig. 3a, b, inset b of Fig. 5). Especially the origin of the buried meandering part of the Karamenderes River, called the Araplar Gorge, is well explained by the transpressional character of fault F3 (Figs. 2a, 3a). The northern submarine extension of the B-BR also lines up with the broad positive flower structure located off the Karaburun Peninsula (Fig. 9). Therefore, fault F3 may actually be connected with the positive flower structure via the NE-SW-oriented B-BR (Figs. 3a, b, 10). The B-BR can thus be interpreted as representing the broad shear zone of a transpressional fault named the BozcaadaBiga Shear Zone (B-BSZ; Fig. 10). Although no data are available to indicate the initiation of the B-BSZ, the geometric similarities with the Gelibolu Fault and the ASZ suggest that this fault may also have been activated in the Pliocene. However, unlike the Gelibolu Fault and the ASZ, the activity of the B-BSZ still continues in fault F3 today (inset $b$ of Fig. 5).

\section{Architecture of the Çanakkale Basin}

Ergin et al. (2007) distinguished the Upper MiocenePliocene deposits, which are coincident with unit 4 of the present study, from the pre-Miocene basement seen on deep multi-channel seismic profiles by correlating these on the western shelf of the Marmara Sea with the onland geology. This interpretation provided the key for the recognition of the boundary of the Canakkale Basin on the NNW-SSEoriented deep multi-channel seismic profile from the western Marmara Sea shelf, and for reconstructing the general architecture of the Çanakkale Basin (Fig. 9). According to the seismic data, the Çanakkale Basin is seen as a broad V-shaped channel filled by Upper Miocene and younger 
deposits. It is delimited along its southeastern and northwestern margins by basement ridges. The seismic data indicate that the southeastern boundary of the basement is controlled by a broad positive flower structure called the B-BSZ (Figs. 9, 10). Along the northern boundary, some reverse faults are also seen to uplift the basement (Fig. 9), indicating that the V-shaped morphology of the Çanakkale Basin is formed by transpressional structures uplifting the basement along the fault zones. Parallel-bedded strata of the Upper Miocene and younger deposits of the Çanakkale Basin are concordantly folded with the basement, forming a V-shaped synclinal structure, which suggests that the compressional forces simultaneously affected at least the lower part of the basin deposits together with the basement (Fig. 9). On the other hand, the parallel bedding of the basin deposits indicates that the sediments were deposited under a relatively low-energy regime, and that they originally formed a horizontally bedded succession comprising fluviolacustrine, beach, and shallow marine sediments. This suggests that the Marmara Sea Basin developed in the Late Miocene during an initial extensional phase when the region was still dominated by a shallow marine to coastal environment.

\section{Morpho-tectonic evolution of the Çanakkale Basin}

Previous studies dealing with the morphological development of the western part of the Marmara region (Yaltırak 1995; Elmas and Meriç 1998; Yaltırak et al. 1998, 2000; Gökaşan et al. 2003; Y1lmaz et al. 2010), together with the recent seismic evidence, indicate that the morpho-tectonic evolution of the Çanakkale Basin may have started as the southern shelf area of the initial Marmara Sea under a N-S extensional regime at the end of the Late Miocene (Fig. 11a). In the Pliocene, the initial stage was followed by the dextral shear tectonics of the NAFZ (Yilmaz et al. 2010). During this period, the Gelibolu Fault and the ASZ were activated, causing the Gelibolu Peninsula to be uplifted to form the northern boundary of the Çanakkale Basin (Fig. 11b). At the same time, the Conkbayır1 Formation was emplaced in front of the ASZ as an alluvial fan and braided river deposit (Sümengen et al. 1987; Yaltırak 1995). Synchronously with the Gelibolu Fault and the ASZ, the B-BSZ was activated to form the southern boundary of the Çanakkale Basin (Fig. 11b). As a consequence, the Çanakkale Basin remained a lowland area wedged between two uplifted basement blocks, eventually evolving into a V-shaped intermontane basin.

While the Gelibolu Fault and the Anafartalar Shear Zone along the northern boundary of the Çanakkale Basin became inactive during the late Pleistocene, the newest (northern) segment of the North Anatolian Fault Zone was initiated. Since this segment has a transtensional character in the Saros Gulf, the transpressional tectonic regime along the gulf, including the northern boundary of the Çanakkale Basin, was transformed into a transtensional one (Fig. 11c). The northern segment of the North Anatolian Fault Zone is accompanied by some secondary active transtensional faults in the Çanakkale Strait, such as the Nara Fault (Gökaşan et al. 2008, 2010). The Bozcaada-Biga Shear Zone, which forms the southern boundary of the Çanakkale Basin, is seismically still active today. The Çanakkale

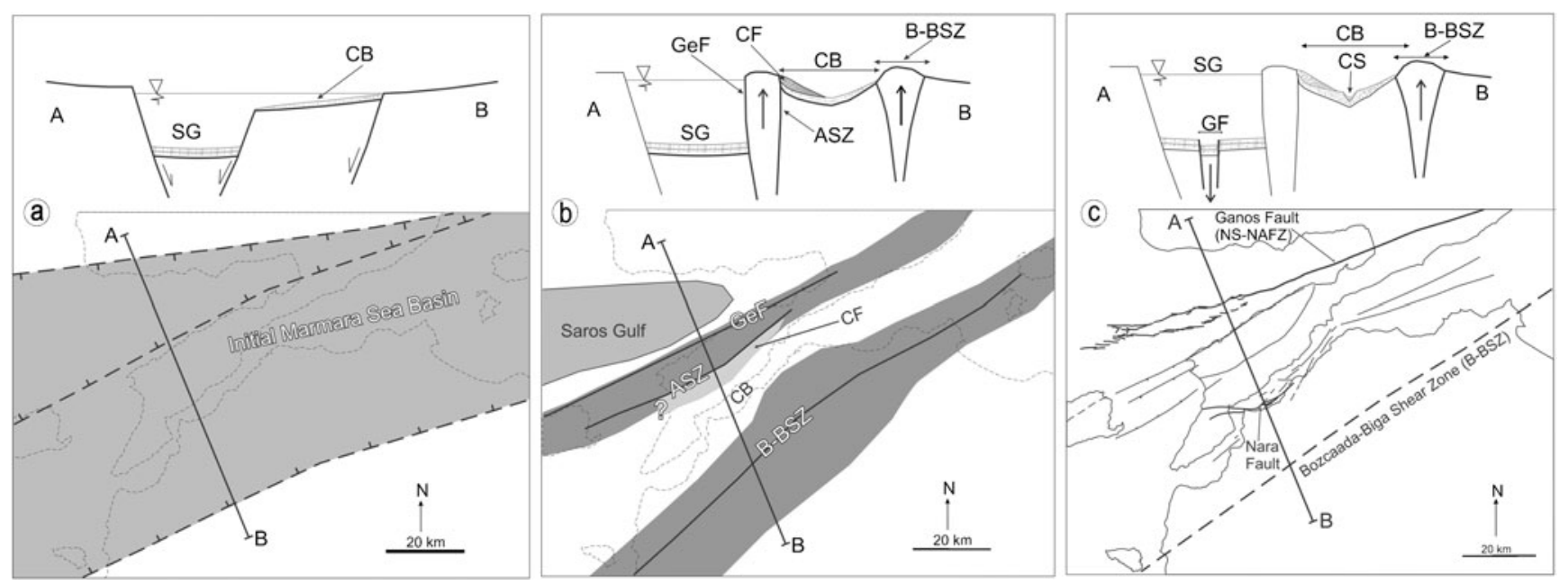

Fig. 11 Evolution of the Çanakkale Basin. a Initiation of the Marmara Sea Basin, the Çanakkale Basin, and the Saros Gulf toward the end of the Late Miocene. b Uplifting of the northwestern and southeastern sides of the Çanakkale Basin by the Gelibolu Fault, the ASZ, and the B-BSZ during the Pliocene to form the basin boundaries, on account of which it became separated from the Saros Gulf. c Replacement of the transpressional tectonism along the northern boundary of the Çanakkale Basin by transtensional tectonics during the late Pleistocene, coinciding with the activation the Ganos Fault along the Saros Gulf. $C B$ Çanakkale Basin, $S G$ Saros Gulf, GeF Gelibolu Fault, $A S Z$ and $B-B S Z$ Anafartalar and Bozcaada-Biga shear zones, respectively, $C F$ Conkbayır Formation, $G F$ Ganos Fault, $A-B$ profile of the section (not to scale) 
Strait, by contrast, was excavated much later along the lowest path of the Çanakkale Basin by erosional forces associated with the latest Mediterranean-Black Sea connection during the late Quaternary.

Acknowledgements This study was supported by the Scientific and Technological Research Council of Turkey, project no. TUBITAKÇAYDAG-104Y024. We thank the Turkish Navy, Department of Navigation, Hydrography, and Oceanography, and the General Directorate of Mineral Research and Exploration for providing the seismic and bathymetric data. Timur Ustaömer provided valuable and constructive criticism on an earlier manuscript. We appreciate the helpful reviews of three anonymous referees and the Editor-in-Chief, Burg W. Flemming.

Open Access This article is distributed under the terms of the Creative Commons Attribution Noncommercial License which permits any noncommercial use, distribution, and reproduction in any medium, provided the original author(s) and source are credited.

\section{References}

Aksu AE, Hiscott RN, Yaşar D (1999) Oscillating Quaternary water levels of the Marmara Sea and vigorous outflow into the Aegean Sea from the Marmara Sea-Black Sea drainage corridor. Mar Geol 153:275-302

Armijo R, Meyer B, Navarro S, King G, Barka A (2002) Asymmetric slip partitioning in the Sea of Marmara pull-apart: a clue to propagation process of the North Anatolian Fault. Terra Nova 14:80-86

Barka AA, Kadinsky-Cade K (1988) Strike-slip fault geometry in Turkey and its influence on earthquake activity. Tectonics 7:663-684

Çağatay N, Görür N, Alpar B, Saatçılar R, Akkök R, Sakınç M, Yüce H, Yaltırak C, Kuşçu I (1998) Geological evolution of the Gulf of Saros, NE Aegean Sea. Geo-Mar Lett 18(1):1-9. doi:10.1007/ s003670050045

Cvijic J (1908) Grundlinien der Geographie und Geologie von Mazedonien und Altserbien. Petermans Mitteilungen Ergänzungsheft I(162), Gotha

Demirbağ E, Gökaşan E, Kurt H, Tepe CM (1998) Approaches about the formation of the NE of the Strait of the Çanakkale (in Turkish). In: Proc Marine Investigations in Turkey, Workshop IV, 14-15 May 1998, Institute of Marine Sciences and Management, Istanbul University, pp 31-38

Elmas A (2003) Late Cenozoic tectonics and stratigraphy of northwestern Anatolia: the effects of the North Anatolian Fault to the region. Int J Earth Sci 92:380-396

Elmas A, Meriç E (1998) The seaway connection between the Sea of Marmara and Mediterranean: tectonic development of the Dardanelles. Int Geol Rev 40(2):144-163

Emre O, Erkal T, Tchepalyga A, Kazancı N, Keçer M, Unay E (1998) Neogene-Quaternary evolution of the eastern Marmara Region (in Turkish). Bull Mineral Resources Explor Turkey 120:223258

Ergin M, Kazancı N, Varol B, İleri Ö, Karadenizli L (1997) Sea-level changes and related depositional environments on the southern Marmara Shelf. Mar Geol 140:391-403

Ergin M, Uluadam E, Sarıkavak K, Keskin E, Gökaşan E, Tur H (2007) Late Quaternary sedimentation and tectonics in the submarine Sarköy Canyon, Western Marmara Sea (Turkey). In: Taymaz T, Y1lmaz Y, Dilek Y (eds) The geodynamics of the Aegean and Anatolia. Geol Soc Lond Spec Publ 291:231-257
Erinç S (2000) Geomorphology I (in Turkish, 5th edn, updated by Ertek A, Güneysu C). Der Press, Istanbul

Erol O (1968) A preliminary report on the geomorphology of the Çanakkale area, the Dardanelles, Turkey. Ankara Univ Bull Geogr Res 2:53-71

Erol O (1992) Geomorphology and tectonics of the Çanakkale region (in Turkish). Bull Turkish Assoc Petrol Geol 4(1):147-165

Erol O, Nuttal CP (1973) Some marine Quaternary deposits in the Dardanelles area (in Turkish). Bull Geogr Invest 5(6):27-91

Gazioğlu C, Gökașan E, Algan O, Yücel ZY, Tok B, Doğan E (2002) Morphologic features of the Marmara Sea from multi-beam data. Mar Geol 190(1/2):333-356

Gökaşan E, Ustaömer T, Gazioğlu C, Yucel ZY, Ozturk K, Tur H, Ecevitoglu B, Tok B (2003) Morpho-tectonic evolution of the Marmara Sea inferred from multi-beam bathymetric and seismic data. Geo-Mar Lett 23(1):19-33. doi:10.1007/ s00367-003-0120-7

Gökaşan E, Tur H, Ecevitoglu B, Görüm T, Türker A, Tok B, Çağlak F, Birkan H, Şimşek M (2005) Evidence and implications of massive erosion along the Strait of İstanbul (Bosphorus). Geo-Mar Lett 25(5):324-342. doi:10.1007/s00367-005-0216-3

Gökașan E, Ergin M, Özyalvaç M, Sur Hİ, Tur H, Görüm T, Ustaömer T, Batuk FG, Alp H, Birkan H, Türker A, Gezgin E, Özturan Ö (2008) Factors controlling the morphological evolution of the Çanakkale Strait (Dardanelles, Turkey). Geo-Mar Lett 28 (2):107-129. doi:10.1007/s00367-007-0094-y

Gökașan E, Tur H, Ergin M, Görüm T, Batuk FG, Sağc1 N, Ustaömer T, Emem O, Alp H (2010) Late Quaternary evolution of the Çanakkale Strait region (Dardanelles, NW Turkey): implications of a major erosional event for the postglacial MediterraneanMarmara Sea connection. Geo-Mar Lett 30(2):113-131. doi:10.1007/s00367-009-0166-2

Gürer ÖF, Kaymakçı N, Çakır Ș, Özburan M (2003) Neotectonics of the southeast Marmara region, NW Anatolia, Turkey. J Asian Earth Sci 21:1041-1051

Gürer ÖF, Sangu E, Özburan M (2006) Neotectonics of the SW Marmara region, NW Anatolia, Turkey. Geol Mag 143(2):229-241

Hiscott RN, Aksu AE (2002) Late Quaternary history of the Marmara Sea and Black Sea from high-resolution seismic and gravity-core studies. Mar Geol 190:261-282

İmren C, Le Pichon X, Rangin C, Demirbağ E, Ecevitoğlu B, Görür N (2001) The North Anatolian Fault within the Sea of Marmara: a new evaluation based on multichannel seismic and multi-beam data. Earth Planet Sci Lett 186:143-158

Karabulut H, Roumelioti Z, Benetatos C, Mutlu AK, Özalaybey S, Aktar M, Kiratzi A (2006) A source study of the 6 July 2003 (Mw 5.7) earthquake sequence in the Gulf of Saros (Northern Aegean Sea): seismological evidence for the western continuation of the Ganos fault. Tectonophysics 412:195-216

Ketin İ (1948) Über die tektonisch-mechanischen Folgerungen aus den grossen anatolischen Erdbeben des letzten Dezenniums. Geol Rundsch 36:77-83

Kurt H, Demirbağ E, Kuşçu İ (2000) Active submarine tectonism and formation of the Gulf of Saros, NE Aegean Sea, inferred from multi-channel seismic reflection data. Mar Geol 165:1326

Le Pichon X, Şengor AMC, Demirbağ E, Rangin C, İmren C, Armijo R, Görür N, Çağatay N, Mercier de Lepinay B, Meyer B, Saatcilar R, Tok B (2001) The active main Marmara Fault. Earth Planet Sci Lett 192:595-616

Okay A, Siyako M, Bürkan AK (1990) Geology and tectonic evolution of the Biga Peninsula (in Turkish). Bull Turkish Assoc Petrol Geol 2:83-121

Okay A, Demirbağ E, Kurt H, Okay N, Kușçu İ (1999) An active, deep marine strike-slip basin along the North Anatolian fault in Turkey. Tectonics 18(1):129-147 
Okay A, Tüysüz O, Kaya Ș (2004) From transpression to transtension: changes in morphology and structure around a bend on the North Anatolian Fault in the Marmara region. Tectonophysics 391:259-282

Pamir HN (1938) On the problem about the formation of the Strait of İstanbul (in Turkish). MTA Bull 3(4):61-69

Reilinger RE, McClusky SC, Oral MB, King RW, Toksöz MN, Barka AA, Kınık I, Lenk O, Şanlı I (1997) Global position system measurements in the Arabia-Africa-Eurasia plate collision zone. J Geophys Res 102:9983-9999

Saatçılar R, Ergintav S, Demirbağ E, İnan S (1999) Character of active faulting in the North Aegean Sea. Mar Geol 160:339-353

Sakınç M, Yaltırak C (2005) Messinian crisis: what happened around the northeastern Aegean? Mar Geol 221:423-436

Saner S (1985) Sedimentary sequences and tectonic setting of the Saros Gulf region, NE Aegean Sea, Turkey (in Turkish). Bull Geol Soc Turkey 28:1-10

Şaroğlu F, Emre Ö, Kuşçu İ (1992) Active fault map of Turkey (in Turkish). Scale 1:2.000.000. Mineral Resources Explor, Turkey Press, Ankara

Şengör AMC (1979) The North Anatolian Transform Fault; its age offset and tectonic significance. J Geol Soc Lond 136:269-282

Șengör AMC (1980) Principles of the neotectonics of Turkey (in Turkish). Geol Soc Turkey Conf Series 2. Geological Society of Turkey, Ankara

Şengör AMC, Görür N, Şaroğlu F (1985) Strike-slip faulting and related basin formation in zones of tectonic escape: Turkey as a case study. SEPM Spec Publ 37:228-264

Șengör AMC, Tüysüz O, İmren C, Sakınç M, Eyidoğan H, Görür N, Le Pichon X, Rangin C (2005) The North Anatolian Fault: a new look. Annu Rev Earth Planet Sci 33:37-112

Seyitoğlu G, Scott BC (1994) Late Cenozoic basin development in west Turkey: Gördes basin: tectonics and sedimentation. Geol Mag 131:631-637

Siyako M, Burkan KA, Okay A (1989) Tertiary geology and hydrocarbon potential of the Biga and Gelibolu peninsulas (in Turkish). Bull Turkish Assoc Petrol Geol 1(3):183-200

Smith AD, Taymaz T, Oktay F, Yüce H, Alpar B, Başaran H, Jackson JA, Kar S, Șimșek M (1995) High-resolution seismic profiling in the Sea of Marmara (Northwest Turkey): Late Quaternary sedimentation and sea-level changes. Geol Soc Am Bull 107:923-936

Sümengen M, Terlemez İ, Șentürk K, Karaköse C, Erkan E, Ünay E, Gürbüz M, Atalay Z (1987) Stratigraphy, sedimentology, and tectonics of the Tertiary sequences in Gelibolu Peninsula and southwestern Thrace (in Turkish). Mineral Resources Explor Turkey Tech Rep 8128

Taymaz T, Jackson J, McKenzie D (1991) Active tectonics of the north and central Aegean Sea. Geophys J Int 106:433-490

Tüysüz O, Barka AA, Yiğitbaș E (1998) Geology of the Saros Graben: its implications on the evolution of the North Anatolian Fault in the Ganos-Saros Region, NW Turkey. Tectonophysics 293:105126

Ustaömer T, Gökașan E, Tur H, Görüm T, Batuk F, Kalafat D, Alp H, Ecevitoğlu B, Birkan H (2008) Faulting, mass-wasting and deposition in an active dextral shear zone, the Gulf of Saros and the NE Aegean Sea, NW Turkey. Geo-Mar Lett 28(3):171193. doi:10.1007/s00367-007-0099-6

Wong HK, Lüdmann T, Uluğ A, Görür N (1995) The Sea of Marmara: a plate boundary sea in an escape tectonic regime. Tectonophysics 244:231-250

Yalçınlar İ (1949) Observations on geomorphology of Çanakkale Strait and surrounding area (in Turkish). Geogr Bull Turkey 8(11/ 12): $129-138$

Yaltırak C (1995) Tectonic mechanism controlling the Plio-Quaternary sedimentation in the Gelibolu Peninsula (in Turkish with English abstract). Geophysics 9(10):103-106

Yaltırak C, Alpar B (2002) Kinematics and evolution of the northern branch of the North Anatolian Fault (Ganos Fault) between the Sea of Marmara and the Gulf of Saros. Mar Geol 190(1/2):351-366

Yaltırak C, Alpar B, Yüce H (1998) Tectonic elements controlling the evolution of the Gulf of Saros (northeastern Aegean Sea, Turkey). Tectonophysics 300:227-248

Yaltırak C, Alpar B, Sakınç M, Yüce H (2000) Origin of the Strait of Çanakkale (Dardanelles): regional tectonics and the MediterraneanMarmara incursion. Mar Geol 164:139-159

Yaltırak C, Sakınç M, Aksu AE, Hiscott RN, Galleb B, Ulgen UB (2002) Late Pleistocene uplift history along the southwestern Marmara Sea determined from raised coastal deposits and global sea-level variations. Mar Geol 190(1/2):283-305

Yılmaz Y, Genç ȘC, Gürer F, Bozcu M, Yılmaz K, Karacık Z, Altunkaynak S,, Elmas A (2000) When did the western Anatolian grabens begin to develop? In: Bozkurt E, Winchester JA, Piper JDA (eds) Tectonics and magmatism in Turkey and surrounding areas. Geol Soc Lond Spec Publ 173:353-384

Y1lmaz Y, Gökaşan E, Erbay AA (2010) Morphotectonic development of the Marmara Region. Tectonophysics 488:51-71 